\title{
Effect of Barley Containing Different Levels of Anthocyanin on the Performance and Egg Quality of Laying Hens
}

\author{
Ho Seong Choe ${ }^{3}$, Tae Hwa Song', Ouk Kyu Han², Tae II Park² and Kyeong Seon Ryu'* \\ ${ }^{1}$ Department of Animal Science, Chonbuk National University, Jeonju 561-756, Korea \\ ${ }^{2}$ Rice and Winter Cereal Crop, NICS, RDA, Iksan 570-080, Korea \\ ${ }^{3}$ Department of Animal Biotechnology, Chonbuk National University, Jeonju 561-756, Korea
}

Received November 22, 2011 /Revised February 5, 2013 / Accepted February 7, 2013

\begin{abstract}
To evaluate the effects of anthocyanin-fortified barley (AFB) and whole crop barley (WCB) addition to diets, 200 Brown Nick hens were assigned to 5 treatments with 5 replicates for 8 weeks. All the treated groups differed in feed intake, egg production, egg weight, and egg mass compared to those of a control group. As the intake of barley was increased, feed intake, egg production, and egg mass decreased. In terms of egg quality, the yolk color (YC), the egg shell breaking strength (SBS), and the egg shell color (SC) differed up to 6 weeks of growth. Feeding the WCB and AFB to laying hens up to 8 weeks had a positive influence on albumin height $(\mathrm{AH})$ and the haugh unit (HU). Up to 6 weeks of growth, increasing the amount of barley in the diets of the laying hens had a positive effect on the SC and the YC but had no effect on the SBS. Diets including 20\% AFB and WCB increased the $\mathrm{AH}$ and $\mathrm{HU}$ to 9.10 and 94.53 , respectively. The results suggest that the addition of AFB and WCB up to $10 \%$ to the diets of laying hens could improve the laying performance and the egg quality.
\end{abstract}

Key words : Laying hen, anthocyanin fortified barley, whole crop barley, performance, egg quality

\section{서 론}

국민소득 2만불 시대에 접어든 우리나라는 늘어난 국민소 득에 따른 식품에 대한 구매 패턴의 변화로 영양은 물론 기능 성이 강화된 식품으로의 소비가 증가되고 있다. 이러한 현상 은 경제성 동물을 이용하여 동물성 식품을 생산하는 축산분야 에서도 동일하게 나타나며 따라서 육, 유제품 내 다양한 기능 성을 부여함으로 시장성을 높이려는 시도가 지속적으로 진행 되고 있다. 육, 유제품 내 well-being과 관련한 기능성 부여는 value added 즉, 기능성 물질의 육, 유제품 내 첨가를 통해 손쉽게 이루질 수 있을 뿐만 아니라 육, 유제품의 특성상 경제 성 동물에 급이되는 사료를 통해서도 그 기능성이 전이될 수 있다. 식물체의 열매, 꽃, 과실, 줄기 잎과 뿌리 등에 폭넓게 존재하며 적색, 자색과 청색의 수용성 색소인 안토시아닌 (anthocyanin)은 플라보노이드계 색소로 착색의 역할과 함께 생체 내 생리활성에 영향을 미친다 $[3,12]$. 따라서 안토시아닌 은 다양한 생리활성으로 인하여 식품 내 기능성을 부과할 수 있는 물질로 손쉽게 이용되고 있다.

\section{${ }^{*}$ Corresponding author}

Tel : +82-63-270-2638, Fax : +82-63-270-2612

E-mail : seon@jbnu.ac.kr

This is an Open-Access article distributed under the terms of the Creative Commons Attribution Non-Commercial License (http://creativecommons.org/licenses/by-nc/3.0) which permits unrestricted non-commercial use, distribution, and reproduction in any medium, provided the original work is properly cited
다양한 플라보노이드 계열의 생리활성 물질과 함께 다량의 안토시아닌을 함유하고 있는 것으로 알려진 보리는 원료사료 의 대부분을 수입에 의존하고 있는 우리나라에서 수입 대체 작물로 그 이용성이 커지고 있다[15]. 더욱이, 보리 내 안토시 아닌의 생리활성 중 특히, 항균과 항산화 작용은 경제성 동물 의 사료 내 항생제 첨가 금지에 대한 대안으로도 긍정적인 작용이 기대된다[11]. 그러나, 보리에는 다량의 식이섬유와 함 께 소수성 성질의 $\beta$-glucan 함량이 높아 사료의 장내 이동속도 를 늦춤으로 $\beta$-glucanase의 첨가를 통해 사료섭취의 저해요인 을 제거해야하는 문제가 있다 $[1,4,6]$. 이러한 문제에도 불구하 고 보리, 특히 낱알을 그대로 이용하는 청보리나 안토시아닌 의 함량을 강화함으로써 보리의 기능성을 강화한 유색보리에 대한 원료 사료화는 동물의 복지와 함께 계란의 기능성 강화 를 위해 산란계 사료에 매우 매력적인 제안이 될 수 있다. 따라서 본 실험은 낱알을 그대로 이용하는 청보리와 더불어 안토시아닌의 함량을 강화한 유색보리의 함량을 산란계 내 사료에 10 혹은 $20 \%$ 로 달리하며 총 8 주간에 걸쳐 급이한다면 급이 산란계군의 생산성과 함께 계란의 품질을 조사함으로써 청보리 혹은 유색보리의 산란계 사료 내 첨가 가능성을 타진 하고자 실시하였다.

\section{재료 및 방법}

\author{
공시동물 및 시험설계 \\ 12 주령의 Brown Nick 산란계 200수를 5처리구에 5반복으
}


로 반복당 8 수씩 공시하였다(treatment $\times$ replicate $\times$ bird $=5 \times$ $5 \times 8)$. 실험 초기인 산란계의 생육 단계에서는 일반 시판사료 $(\mathrm{ME}=2750 \mathrm{kcal} / \mathrm{kg}, \mathrm{CP}=16 \%)$ 의 급이와 더불어 16 주령까지는 자연광을 이용한 점등에서 17 주령부터는 14 시간의 점등을 시 행하였다. 이후, 1 주 간격으로 30 분씩 점등을 증가시키며 점등 시간이 16 시간에 도달하는 21 주령부터 사양 실험을 실시하였 다. 대조구와 함께 처리구로는 국립식량과학원 벼맥류부에서 공급한 유색보리(anthocyanin fortified barley)와 청보리(whole crop barley)를 각각 5,10 와 $15 \%$ 씩 첨가한 사료를 급이하 며 총 8 주에 걸쳐 사양하였다(Table 1). 사양 전 기간 동안 산란 계는 사료와 물을 자유롭게 섭취할 수 있도록 하였으며, 모든 실험은 전북대학교 동물실험위원회의 규정을 준수하며 수행 하였다.

\section{조사항목 \\ 생 산성}

총 8 주의 시험기간 동안 계란을 일 단위로 수집하며 대조구 와 처리구별 산란율과 난중을 조사하였으며, 사료섭취량은 4 주 단위로 사료잔량을 측정한 다음 사료급여량을 공제함으로 써 산출하였다. 일산란량은 산란율과 평균 난중을 곱하여 계
산하였으며 사료섭취량을 산란량으로 나눔으로 사료요구율 을 도출하였다.

\section{난품질}

계란의 품질 측정을 위하여 총 8 주의 사양기간 중 $2,4,6$ 과 8 주의 금요일에 처리구별로 30 개의 계란을 임의로 선발, 이용 하며 각각의 품질을 측정하였다. 난각강도는 난각강도 측정기 (QC-SPA, TSS, UK)를 사용하였으며, 난색도, 난백고, 호우유 닛(신선도)과 난황색도는 난품질 측정기 $\left(\mathrm{QCM}^{+}, \mathrm{TSS}, \mathrm{UK}\right)$ 를 이용하며 측정하였다.

\section{통계처리}

수집된 모든 결과들의 통계처리는 SAS [13] 프로그램을 활 용하여 분산분석(GLM)을 실시하였으며, 처리구간 유의성 검 정은 Duncan's multiple range test를 이용하여 $95 \%$ 수준에서 유의성 검정을 실시하였다.

\section{결과 및 고찰}

Table 2는 유색보리 또는 청보리를 산란계 사료 내 첨가하 여 총 200수의 산란계에 8 주간 급이하며 사양한다면 사료요구

Table 1. Composition of experimental diets

\begin{tabular}{|c|c|c|c|c|c|}
\hline & \multirow{2}{*}{ Control } & \multicolumn{2}{|c|}{ Anthocyanin fortified barley (\%) } & \multicolumn{2}{|c|}{ Whole crop barley $(\%)$} \\
\hline & & 10 & 20 & 10 & 20 \\
\hline Corn & 64.95 & 60.48 & 54.33 & 59.66 & 53.18 \\
\hline Soybean meal & 13.35 & 10.10 & 0.17 & 11.35 & 1.19 \\
\hline Corn gluten meal & 4.79 & 8.24 & 14.08 & 7.84 & 14.25 \\
\hline Wheat bran & 3.00 & - & - & - & - \\
\hline Rapeseed meal & 3.00 & - & - & - & - \\
\hline Limestone & 9.22 & 9.35 & 9.34 & 9.33 & 9.29 \\
\hline Di-calcium phosphate & 0.97 & 0.96 & 1.02 & 0.99 & 1.07 \\
\hline Salt & 0.37 & 0.38 & 0.37 & 0.37 & 0.36 \\
\hline L-lysine & 0.12 & 0.25 & 0.47 & 0.22 & 0.44 \\
\hline DL-methionine & 0.03 & 0.04 & 0.02 & 0.04 & 0.02 \\
\hline Vitamine premix ${ }^{1}$ & 0.10 & 0.10 & 0.10 & 0.10 & 0.10 \\
\hline Mineral premix ${ }^{2}$ & 0.10 & 0.10 & 0.10 & 0.10 & 0.10 \\
\hline Whole crop barley & - & - & - & 10.00 & 20.00 \\
\hline Colored barley & - & 10.00 & 20.00 & - & - \\
\hline Total & \multicolumn{5}{|c|}{--------------- 100.00 --------------- } \\
\hline \multicolumn{6}{|l|}{ Chemical composition } \\
\hline$\overline{\mathrm{ME}}(\mathrm{kcal} / \mathrm{kg})$ & 2,750 & 2,750 & 2,750 & 2,750 & 2,750 \\
\hline $\mathrm{CP}(\%)$ & 16.00 & 16.00 & 16.00 & 16.00 & 16.00 \\
\hline Lysine (\%) & 0.76 & 0.76 & 0.76 & 0.76 & 0.76 \\
\hline Methionin (\%) & 0.33 & 0.33 & 0.33 & 0.33 & 0.33 \\
\hline $\mathrm{Ca}(\%)$ & 3.75 & 3.75 & 3.75 & 3.75 & 3.75 \\
\hline $\mathrm{Na}(\%)$ & 0.17 & 0.17 & 0.17 & 0.17 & 0.17 \\
\hline Available phosphate (\%) & 0.28 & 0.28 & 0.28 & 0.28 & 0.28 \\
\hline
\end{tabular}

${ }^{1}$ Contain per kg: vit A 12,000,000 IU; vit D3 5,000,000 IU; vit E 50,000 mg; vit K3 3,000 mg; vit B1 2,000 mg; vit B2 6,000 mg; vit B6 4,000 mg; vit B12 $25 \mathrm{mg}$; biotin $150 \mathrm{mg}$; pantothenic acid 20,000 mg; folic acid 2,000 mg; nicotinic acid 7,000 mg.

${ }^{2}$ Contain per kg; Fe 66,720 mg; Cu 41,700 mg; Mn 83,400 mg; Zn 66,720 mg; I 834 mg; Se 250 mg. 
율인 FCR은 일반 시판사료를 급이한 대조구(2.39)와 유의하지 않았다( $p>0.05)$. 그러나, 보리의 급이는 사료섭취량, 산란율과 일산란량에서 대조구와 통계적으로 유의하였으며 특히, 사료 섭취량, 산란율과 일산란량은 유색보리와 청보리를 10 에서 $20 \%$ 로 사료 내 첨가량을 증가시킴에 따라 유의적으로 감소하 였다 $(p<0.05)$. 선행 연구들에 의하면 유색 혹은 청보리의 5- $15 \%$ 첨가·급이는 $\beta$-glucan을 함유한 고섬유질 원료인 보리 의 급이에 의해 증가된 장내 점성으로 사료의 이동속도가 저 하되고 따라서 일정 에너지 수준을 유지하기 위하여 사료섭취 량이 증가하였다고 보고한 바 있다 $[1,5,8,10,15]$. 그러나, 본 실험 내 보리 사료의 급이는 일반 시판사료를 급이한 대조 구의 사료섭취량보다 유의적으로 낮은 $101.31-125.62 \mathrm{~g}$ 의 사료 를 섭취함으로써 줄어든 사료섭취량과 함께 수치적으로 개선 된 사료요구율을 나타내었다(p>0.05). 난중 또한 산란계 사료 내 보리의 첨가가 유의적으로 계란의 무게를 줄였으나 $(p<0.05)$ 보리의 종류 혹은 첨가량에 따른 영향은 없었다 ( $p>0.05)$.

유색보리 혹은 청보리의 산란계 사료 내 첨가·급이는 보리 급이 2 주차에 생산된 계란의 난황색과 난각강도에 유의적으 로 작용하였으나 $(p<0.05)$ 난색도, 난백고와 호우유닛은 처리 구간 통계적 유의차가 없었다(p>0.05)(Table 3). 난색도, 난백 고와 호우유닛은 각각 대조구의 24.52, 9.16 그리고 94.34 와 유 사한 25.35-26.85, 9.31-9.66과 95.84-97.17이었다. 산란계에 유 색보리 혹은 청보리의 급이를 10 에서 $20 \%$ 로 높인다면 난황색 은 농도에 따라 유의적으로 증가하며 특히, 청보리의 $20 \%$ 첨
가는 7.85 의 난황색을 나타내었다 $(p<0.05)$. 본 실험은 일반적 으로 옥수수의 일부 대체를 위해 보리를 첨가함에 따라 $\beta$-carotene의 난황 내 침착을 감소시키나 보리 내 다양한 색소에 의해 대조구 계란의 난황색 보다 높은 난황색도를 나타낸 것 으로 판단된다 $[7,9]$. 더욱이, 유색보리의 첨가는 난각강도를 수치적으로 증가시켰으며 특히 $5 \%$ 의 청보리 첨가·급이는 유 의적으로 높은 5.32의 난각강도를 나타내었다 $(p<0.05)$.

계란의 난각색, 난황색과 난각강도는 유색보리 혹은 청보리 의 첨가 혹은 보리의 첨가량에 따라 유의적으로 감소 또는 증가하였다( $p \times 0.05$ )(Table 4). 그러나, 난백고와 호우유닛은 대 조구와 보리 첨가구들에서는 Benabdeljelil과 Arbaoui [2]의 결과에서처럼 유의성이 없었다(p>0.05). 유색보리를 5\% 산란 계 사료에 첨가하며 4 주간 급이한다면 난각색은 유의적으로 증가하여 24.90인 대조구보다 2.45 높은 27.35를 나타내었으며 유색보리와 더불어 청보리의 첨가·급이는 난황색을 7.75-8.10 으로 향상시켰다 $(p<0.05) .20 \%$ 의 청보리는 난각강도에 유의적 인 영향을 미치며 4.92 인 대조구의 난각강도보다 낮은 3.99의 난각강도를 나타내었다( $p<0.05)$. 이러한 난각강도의 변화는 유색보리와 청보리를 급이한 산란계에서 생산된 계란의 난각 강도가 0 주 이후 대조구와 통계적 유의성이 없었던 송 등[15] 의 결과와는 다소 차이가 있었다.

6주간의 사양을 통해 생산된 계란의 품질에서도 난각색과 난황색은 유색 혹은 청보리의 급여에 따라 대조구 대비 유의 적으로 증가하였다( $p<0.05)$ (Table 5). 그러나, 또 다른 계란 품 질 계측 항목이라 할 수 있는 난백고, 호우유닛과 난각강도는

Table 2. Effect of two different barley addition in laying hen diets on performance

\begin{tabular}{lccccc}
\hline Treatment $^{1}$ & Feed intake $(\mathrm{g})$ & Egg production $(\%)$ & Egg weight $(\mathrm{g})$ & Egg mass & FCR $^{2}$ \\
\hline Control & $133.54 \pm 6.76^{\mathrm{a}}$ & $89.44 \pm 1.50^{\mathrm{a}}$ & $62.68 \pm 0.24^{\mathrm{a}}$ & $56.05 \pm 0.80^{\mathrm{a}}$ & $2.39 \pm 0.15$ \\
AFB10 & $121.89 \pm 1.57^{\mathrm{b}}$ & $89.11 \pm 2.11^{\mathrm{a}}$ & $61.10 \pm 0.13^{\mathrm{b}}$ & $54.02 \pm 1.36^{\mathrm{a}}$ & $2.26 \pm 0.08$ \\
AFB20 & $101.31 \pm 2.21^{\mathrm{c}}$ & $72.58 \pm 4.06^{\mathrm{b}}$ & $60.02 \pm 0.44^{\mathrm{b}}$ & $43.65 \pm 2.68^{\mathrm{b}}$ & $2.34 \pm 0.13$ \\
WCB10 & $125.62 \pm 1.97^{\mathrm{ab}}$ & $90.11 \pm 0.36^{\mathrm{a}}$ & $61.42 \pm 0.45^{\mathrm{b}}$ & $55.36 \pm 0.19^{\mathrm{a}}$ & $2.27 \pm 0.03$ \\
WCB20 & $109.29 \pm 0.73^{\mathrm{c}}$ & $79.22 \pm 0.38^{\mathrm{b}}$ & $60.44 \pm 0.54^{\mathrm{b}}$ & $47.83 \pm 0.49^{\mathrm{b}}$ & $2.29 \pm 0.01$ \\
\hline
\end{tabular}

${ }_{1}^{1} \mathrm{AFB}=$ anthocyanin fortified barley; $\mathrm{WCB}=$ whole crop barley.

${ }^{2}$ Feed conversion ratio.

${ }^{a, b, c}$ Mean values within a column followed by the same letter are not significantly different $(p>0.05)$.

Values are mean \pm SE.

Table 3. Effect of two different type barley addition in laying hen diets on egg quality at 2 weeks of growth

\begin{tabular}{lccccc}
\hline Treatment $^{1}$ & Egg shell color & Albumin height & Haugh unit & Yolk color & Egg shell breaking strength \\
\hline Control & $24.52 \pm 0.81$ & $9.16 \pm 0.29$ & $94.34 \pm 1.43$ & $7.05 \pm 0.05^{\mathrm{c}}$ & $4.61 \pm 0.20^{\mathrm{b}}$ \\
AFB10 & $26.85 \pm 0.82$ & $9.31 \pm 0.17$ & $95.84 \pm 0.84$ & $7.45 \pm 0.11^{\mathrm{b}}$ & $4.88 \pm 0.21^{\mathrm{ab}}$ \\
AFB20 & $26.47 \pm 0.99$ & $9.66 \pm 0.32$ & $97.17 \pm 1.40$ & $7.73 \pm 0.14^{\mathrm{ab}}$ & $4.91 \pm 0.21^{\mathrm{ab}}$ \\
WCB10 & $25.65 \pm 0.90$ & $9.59 \pm 0.18$ & $97.07 \pm 0.86$ & $7.50 \pm 0.11^{\mathrm{b}}$ & $5.32 \pm 0.16^{\mathrm{a}}$ \\
WCB20 & $25.35 \pm 0.91$ & $9.36 \pm 0.29$ & $96.09 \pm 1.34$ & $7.85 \pm 0.10^{\mathrm{a}}$ & $4.32 \pm 0.19^{\mathrm{b}}$ \\
\hline
\end{tabular}

${ }^{1} \mathrm{AFB}=$ anthocyanin fortified barley; $\mathrm{WCB}=$ whole crop barley.

$a, b, c$ Mean values within a column followed by the same letter are not significantly different $(p>0.05)$.

Values are mean \pm SE. 
Table 4. Effect of two different type barley addition in laying hen diets on egg quality at 4 weeks of growth

\begin{tabular}{lccccc}
\hline Treatment $^{1}$ & Egg shell color & Albumin height & Haugh unit & Yolk color & Egg shell breaking strength \\
\hline Control & $24.90 \pm 0.77^{\mathrm{b}}$ & $9.05 \pm 0.18$ & $94.07 \pm 0.98$ & $7.55 \pm 0.11^{\mathrm{b}}$ & $4.92 \pm 0.12^{\mathrm{a}}$ \\
AFB10 & $27.35 \pm 0.84^{\mathrm{a}}$ & $9.15 \pm 0.18$ & $94.78 \pm 0.88$ & $8.10 \pm 0.12^{\mathrm{a}}$ & $5.00 \pm 0.22^{\mathrm{a}}$ \\
AFB20 & $24.55 \pm 1.02^{\mathrm{b}}$ & $9.49 \pm 0.25$ & $96.60 \pm 1.15$ & $7.95 \pm 0.15^{\mathrm{a}}$ & $4.82 \pm 0.20^{\mathrm{a}}$ \\
WCB10 & $24.20 \pm 0.57^{\mathrm{b}}$ & $9.67 \pm 0.31$ & $96.94 \pm 1.44$ & $7.75 \pm 0.12^{\mathrm{ab}}$ & $4.85 \pm 0.21^{\mathrm{a}}$ \\
WCB20 & $24.20 \pm 0.84^{\mathrm{b}}$ & $9.51 \pm 0.28$ & $96.56 \pm 1.23$ & $8.10 \pm 0.12^{\mathrm{a}}$ & $3.99 \pm 0.22^{\mathrm{b}}$ \\
\hline
\end{tabular}

${ }^{1} \mathrm{AFB}=$ anthocyanin fortified barley; $\mathrm{WCB}=$ whole crop barley.

a,b Mean values within a column followed by the same letter are not significantly different $(p>0.05)$.

Values are mean \pm SE.

Table 5. Effect of two different type barley addition in laying hen diets on egg quality at 6 weeks of growth

\begin{tabular}{lccccc}
\hline Treatment $^{1}$ & Egg shell color & Albumin height & Haugh unit & Yolk color & Egg shell breaking strength \\
\hline Control & $26.20 \pm 0.75^{\mathrm{b}}$ & $9.24 \pm 0.22$ & $94.89 \pm 1.06$ & $7.35 \pm 0.15^{\mathrm{b}}$ & $4.14 \pm 0.20$ \\
AFB10 & $29.70 \pm 0.86^{\mathrm{a}}$ & $8.73 \pm 0.42$ & $92.08 \pm 2.50$ & $7.85 \pm 0.13^{\mathrm{a}}$ & $4.40 \pm 0.19$ \\
AFB20 & $30.10 \pm 1.06^{\mathrm{a}}$ & $9.08 \pm 0.20$ & $94.73 \pm 0.85$ & $8.20 \pm 0.17^{\mathrm{a}}$ & $4.14 \pm 0.25$ \\
WCB10 & $27.75 \pm 0.70^{\mathrm{ab}}$ & $9.36 \pm 0.22$ & $95.72 \pm 1.11$ & $8.15 \pm 0.13^{\mathrm{a}}$ & $4.56 \pm 0.24$ \\
WCB20 & $28.30 \pm 0.88^{\mathrm{ab}}$ & $9.05 \pm 0.31$ & $94.06 \pm 1.44$ & $8.25 \pm 0.19^{\mathrm{a}}$ & $4.18 \pm 0.20$ \\
\hline
\end{tabular}

${ }^{1} \mathrm{AFB}=$ anthocyanin fortified barley; $\mathrm{WCB}=$ whole crop barley.

${ }^{a, b}$ Mean values within a column followed by the same letter are not significantly different $(p>0.05)$.

Values are mean \pm SE.

Table 6. Effect of two different type barley addition in laying hen diets on egg quality at 8 weeks of growth

\begin{tabular}{lcclcc}
\hline Treatment $^{1}$ & Egg shell color & Albumin height & Haugh unit & Yolk color & Egg shell breaking strength \\
\hline Control & $26.93 \pm 0.66$ & $8.27 \pm 0.15^{\mathrm{b}}$ & $89.77 \pm 0.85^{\mathrm{bc}}$ & $7.37 \pm 0.10^{\mathrm{c}}$ & $3.94 \pm 0.15$ \\
AFB10 & $26.53 \pm 0.72$ & $8.27 \pm 0.20^{\mathrm{b}}$ & $89.17 \pm 1.16^{\mathrm{c}}$ & $7.80 \pm 0.09^{\mathrm{b}}$ & $3.99 \pm 0.20$ \\
AFB20 & $27.63 \pm 0.57$ & $8.60 \pm 0.19^{\mathrm{a}}$ & $91.88 \pm 0.98^{\mathrm{abc}}$ & $8.63 \pm 0.10^{\mathrm{a}}$ & $3.84 \pm 0.15$ \\
WCB10 & $27.73 \pm 0.66$ & $8.86 \pm 0.27^{\mathrm{ab}}$ & $92.41 \pm 1.41^{\mathrm{ab}}$ & $8.07 \pm 0.12^{\mathrm{b}}$ & $4.19 \pm 0.16$ \\
WCB20 & $27.00 \pm 0.53$ & $9.10 \pm 0.17^{\mathrm{a}}$ & $94.53 \pm 0.76^{\mathrm{a}}$ & $8.50 \pm 0.12^{\mathrm{a}}$ & $3.93 \pm 0.22$ \\
\hline
\end{tabular}

${ }^{1} \mathrm{AFB}=$ anthocyanin fortified barley; $\mathrm{WCB}=$ whole crop barley.

$a, b, c$ Mean values within a column followed by the same letter are not significantly different $(p>0.05)$.

Values are mean \pm SE.

대조구와 보리 급이 처리구간 통계적 유의성이 없었다 (p>0.05). 사양 6주차에 생산된 계란은 유색보리 급이 처리구 에서 유의적으로 높은 29.70-30.10의 난각색을 나타내었다. 더 욱이, 난황색의 경우에는 유색 혹은 청보리의 급이가 7.35 인 대조구의 난황색보다 유의적으로 높은 7.85-8.25의 난황색과 $(p<0.05)$ 함께 수치적으로도 보리 함량의 증가는 난황색의 증 가를 나타내었다( $p>0.05)$. 보리의 성숙에 따라 $\beta$-carotene의 보리 내 농도는 점차 감소함으로 보리 급이에 따른 난황색도 의 증가는 앞서 언급한 $\beta$-carotene의 난황 내 축적에 의하기 보다는 $\beta$-carotene 이외의 carotinoids 혹은 이외의 생리활성 물질에 따른 것으로 판단된다[14].

Table 6 은 8 주간의 유색 혹은 청보리의 급이가 계란의 품질 에 미치는 영향을 나타내었다. 난각색과 난각강도는 보리의 급이가 통계적인 영향을 미치지는 않았으나 $(p>0.05)$ 난백고, 호우유닛과 난황색에서는 유의적인 영향이 있었다 $(p<0.05)$. 청보리의 급이는 유의적으로 높은 난백고를 나타내어 사료
내 청보리의 함량을 10 에서 $20 \%$ 로 증가시킨다면 난백고 또한 수치적으로 증가하였으며 특히 유색보리의 증가는 난백고를 8.27 에서 8.60으로 증가시켰다( $p<0.05)$. 호우유닛은 유색보리 의 급이로는 대조구와 유의성이 없었으나 $20 \%$ 의 청보리를 급 이한다면 호우유닛을 94.53 까지 증가시켰다( $\beta<0.05)$. 2 주의 보 리 사료 급이때부터 나타난 난황색의 통계적 유의성은 8주차 계란에서도 유의하게 나타났으며 특히 유색보리와 청보리의 사료 내 첨가량이 $20 \%$ 일때 유의적으로도 높은 8.63 과 8.50 의 난황색을 나타내었다 $(p<0.05)$.

따라서, 본 실험은 낱알을 그대로 급이하는 청보리와 안토 시아닌 강화 보리인 유색보리를 총 8 주에 걸쳐 산란계에 급이 한다면 산란율과 일산란량에는 영향을 미치지 않으면서도 사 료요구율을 수치적으로 감소시키며 계란의 품질 중 난백고, 호우유닛과 난황색 또한 일반 시판 계란과 유사한 계란의 생 산을 가능하게 하는 청보리 혹은 유색보리의 산란계 사료 내 첨가는 최대 $10 \%$ 까지 가능할 것으로 판단된다. 


\section{감사의 글}

본 연구는 농촌진흥청 공동연구사업 수행에 의한 결과 중 일부로 연구비 지원에 감사드립니다.

\section{References}

1. Aastrup, S. 1979. The effect of rain on $\beta$-glucan content in barley grain. Carlsberg Res Comm 44, 381-393.

2. Benabdeljelil, K. and Arbaoui, M. I. 1994. Effects of enzyme supplementation of barley-based diets on hen performance and egg quality. Anim Feed Sci Tech 48, 325-334.

3. Francis, F. J. 1989. Food colorants: Anthocyanins. Crit ReV Food Sci Nutr 28, 273-314.

4. Gohl, B. and Thomke, S. 1976. Digestibility coefficients and metabolizable energy of barley diets for layers as influenced by geographical area of production. Poult Sci 55, 2369-2374.

5. Harms, R. H. and Waldroup, P. W. 1963. Further studies on diet composition on egg weight. Poult Sci 42, 657-662.

6. Kalra, S. and Jood, S. 2000. Effect of dietary barley $\beta$-glucan on cholesterol and lipoprotein fractions in rats. J Cereal SCi 31, 141-145.

7. Lee, J. H., Kim, K. S., Shin, S. O., Cho, J. H., Chen, Y. J. and Kim, I. H. 2007. Effects of dietary pine cone meal on egg production, egg quality, serum cholesterol and cholesterol content and fatty acid composition of egg yolk in laying hens. Korean J Poult Sci 34, 223-229.

8. Marlett, J. A. 1991. Dietary fiber content and effect of processing on two barley varieties. Cereal Food World 36, 576.

9. Na, J. C. 2003. $20^{\text {th }}$ Proceedings of the Korea society of poultry science conference. 16, 9-27.

10. Oh, H. J. and Lee, S. R. 1996. Physiological function in vitro of B-glucan isolated from barley. Korean J Food Sci Technol 28, 689-695.

11. Park, Y. S., Kim, J. R., Kang, B. K., Choe, Y. H. and Kim, B. S. 2012. Inhibitory effects of herbal medicine on coccidiosis. Korean J Vet Serv 35, 25-31.

12. Prior, R. L., Cao, G., Martin, A., Sofic, E., McEwen, J., O'Brien, C., Lischner, N., Ehlenfeldt, M., Kalt, W., Krewer, G. and Mainland, C. M. 1998. Antioxidant capacity as influenced by total phenolic and anthocyanin content, maturity and variety of Vaccinium species. J Agric Food Chem 46, 2686-2693.

13. SAS. 2008. SAS/STAT Software. Release 9.2, SAS Institute Inc., Cary, NC, USA.

14. Smith, A. M. and Robb, W. 1943. The carotene and protein in oats and barley at different stages of growth. J Agric SCi 33, 119-121.

15. Song, T. H., Han, O. K., Park, T. I., Park, K. H., Kim, K. J., Yoon, M. J., Jeong, Y. D. and Ryu, K. S. 2011. Effect of feeding colored barley and whole crop barley on performance, egg quality and blood composition of laying hens. Korean J Anim Sci Tech 53, 127-132.

\section{초록 : 안토시아닌의 함량을 달리한 보리의 급여가 산란계의 생산성과 계란품질에 미치는 영향 \\ 최호성 ${ }^{3} \cdot$ 송태화 $^{2} \cdot$ 한옥규 $^{2} \cdot$ 박태일 $^{2} \cdot$ 류경선 $^{1} \star$ \\ ( ${ }^{1}$ 전북대학교 동물자원과학과, ${ }^{2}$ 국립식량과학원 벼맥류부, ${ }^{3}$ 전북대학교 동물생명공학과)}

산란계 사료 내 유색보리 혹은 청보리의 10 또는 $20 \%$ 첨가가 산란계의 생산성과 계란 품질에 미치는 영향을 조사하기 위하여 총 200 마리의 Brown nick을 5 처리구에 5 반복으로 배치하며 8 주간 사양하였다. 시험군의 사료 섭취량, 산란율, 난중과 일산란량은 대조구와 유의성 있게 달랐으며 특히 사료섭취량, 산란량과 일산란량은 보리 의 함량이 증가할수록 유의적으로 감소하였다. 계란의 품질 중 난황색, 난각강도 또는 난각색은 사양 6 주차까지 의 보리 시험군에서 유의하였으나 보리를 8 주차까지 급이한다면 난백고와 더불어 호우유닛에 긍정적인 영향을 나타내었다. 사양 6 주까지에 대한 보리의 급이는 난각색과 난황색의 수치를 첨가량에 따라 유의적으로 높인 반면 난각강도에 대한 유의성은 없었다. 산란계 사료 내 보리의 함량을 $20 \%$ 로 증가시켜 급이한다면 난백고와 호우유 닛은 유의적으로 증가하였으며 특히, 유색보리보다는 청보리의 첨가군에서 수치적으로 높은 9.10과 94.53의 난백 고와 호우유닛을 나타내었다. 따라서 본 연구에서는 산란계의 생산성과 계란의 품질을 고려한 보리 첨가 산란계 사료를 생산하고자 한다면 생산성에서는 대조구와 유사하면서도 계란의 품질을 향상시킨 청보리 혹은 유색보리 를 최대 $10 \%$ 까지 첨가한 산란계 사료의 생산을 고려해 볼 수 있을 것으로 판단된다. 